\title{
Social ties, prior experience, and venture creation by transnational entrepreneurs
}

\author{
Sarika Pruthi* \\ School of Global Innovation \& Leadership, \\ Lucas College \& Graduate School of Business, \\ San Jose State University (SJSU), \\ Business Tower 950, One Washington Square, \\ San José, CA 95192-0065, USA \\ Email: sarika.pruthi@sjsu.edu \\ *Corresponding author

\section{Mike Wright} \\ Enterprise Research Centre, \\ Imperial College Business School, \\ Imperial College London, \\ Tanaka Building, South Kensington Campus, \\ London SW7 2AZ, UK \\ Email: mike.wright@imperial.ac.uk
}

\begin{abstract}
The interaction between resources, and host and home country contexts of transnational entrepreneurs (TEs), is important for understanding their strategies and hence performance of their ventures. Yet, how they deploy their unique experiences and social networks in the founding of ventures in multiple institutional contexts is less understood. Based on 15 in-depth interviews with TEs of Indian origin in the UK, and nine of their counterpart heads of transnational venture (TNV) operations, we explore the use of prior experience, and personal and industry ties in the founding of TNVs in their home country. Our findings show that the way TEs use personal and industry ties in the host and home countries is contingent on whether they have prior experience of: 1) entering the home country; 2) implementing the business opportunity underlying the TNV in the home country, respectively, with a former employer. The implications of these findings are discussed.
\end{abstract}

Keywords: social ties; venture creation; transnational entrepreneurs; TEs; UK; India.

Reference to this paper should be made as follows: Pruthi, S. and Wright, M. (2019) 'Social ties, prior experience, and venture creation by transnational entrepreneurs', Int. J. Entrepreneurship and Small Business, Vol. 36, Nos. 1/2, pp.41-73.

Biographical notes: Sarika Pruthi is an Assistant Professor in Entrepreneurship at San Jose State University (SJSU), California. Her research examines international venture capital, entrepreneurship in emerging economies, and transnational and returnee entrepreneurship. Her work has appeared in the Asia Pacific Journal of Management, International Business Review, International Journal of Management Reviews, and Strategic Management Journal, among others. She currently serves on the editorial board 
of the Journal of Entrepreneurship and Innovation in Emerging Economies. Prior to joining SJSU, she taught and researched at King's College London, University of London, and the University of Nottingham (UK) where she also earned her MA and $\mathrm{PhD}$.

Mike Wright is a Professor of Entrepreneurship at Imperial College Business School (University of London), the Director of the Center for Management Buyout Research, and a Visiting Professor at ETH Zurich and University of Ghent. His research focuses on entrepreneurial ownership mobility on which he has published many papers in leading international journals. He is the Chair of the Society for the Advancement of Management Studies, and the Editor of Academy of Management Perspectives.

\section{Introduction}

Studies in entrepreneurship recognise the interplay between social and human capital in venture creation (Anderson and Miller, 2003; Davidsson and Honig, 2003). Although studies acknowledge the challenges of venture creation across geographic borders, entrepreneurship literature is criticised for the relative lack of attention to the intersection of individual resources and country contexts in venture founding (Terjesen and Elam, 2009; Waldinger and Fitzgerald, 2004). In this paper, we focus on the interaction between prior experience and use of social ties in venture creation in the host and home countries by transnational entrepreneurs (TEs). Social ties are defined as the strength and quality of relations within an entrepreneur's network (Jack, 2005). TEs migrate from one country to another and concurrently maintain a link with their home and currently adopted (host) countries (Drori et al., 2009). Unlike ethnic entrepreneurs (EEs) that found a venture in their new country of residence or returnee entrepreneurs (REs) that permanently return home after living or working abroad, TEs travel both physically and virtually to simultaneously engage in two institutional environments in the host and home countries, which may have implications for the interaction between their prior experience and social ties in venture founding. Indeed Davidsson and Honig (2003) argue that human capital facilitates successful outcomes only in conjunction with appropriate social capital.

Entrepreneurs that found a venture in multiple institutional environments need to develop dual capabilities based on their unique experiences and social networks in order to operate in these environments (Chen and Tan, 2009). Social ties of TEs from home may help in adapting to the host country while those in the host country may provide social capital that enhances opportunities and helps overcome institutional constraints in venture founding at home (Tang, 2011).

Compared to entrepreneurs in a single geographic setting, TEs operate in a context that is international at inception. Unlike entrepreneurs embedded in the host country after making a one-way move from the home country, or return home to found a venture after living abroad, TEs traverse both host and home countries in venture founding. As such, TEs are faced with the dual challenge of developing and maintaining ties in home and host country. It is difficult to do so without geographical proximity (Inkpen and Tsang, 2005). TEs may exploit personal ties they already possess. However, home networks may have been influential in selecting a destination for migrants, but these home networks may then depreciate as they need to rely less on them than on the networks in their ethnic 
conclaves in the host country (Light and Gold, 2000). Further, while the migrant literature has tended to emphasise the importance of personal ethnic ties, TEs may not necessarily possess such ties or personal ties may be of limited help especially when the business opportunity they have identified goes beyond the boundary of the ethnic environment (Drori et al., 2009). In such circumstances, TEs may need to develop new ties that substitute for or complement personal ties. They may need to go beyond ethnicity of friends and family to build new ties based on how their prior experience relates to the business opportunity for their venture. They may rely on industry ties in one or both countries if they have previously worked as an employee of another company. The use of personal or industry ties may also depend on whether prior experience of living or working in the home country is gained before migrating to the host country, or upon re-connecting with the home country after first migrating abroad.

The interaction between social and human capital of entrepreneurs is important for understanding their strategies and hence performance of their ventures (Yang et al., 2012). As TEs are distinctive by virtue of being situated in two institutional environments, understanding the nature of interaction between their prior experience and use of social ties in venture founding in these contexts opens up the possibility for new insights regarding the behaviour and contribution of TEs that go beyond the insights available in the existing migrant literature that has tended to focus on personal ethnic ties. The use of personal as well as industry ties of TEs is important because of the implications for the nature of relationships that subsequently develop and hence growth of their ventures (Sullivan and Ford, 2013). Whereas personal, family ties of TEs may be a source of both new ideas and support in venture creation (Bagwell, 2007), industry ties can facilitate transfers of skills and knowhow across geographical borders, particularly between very different business cultures and environments (Saxenian and Hsu, 2001). Typically, entrepreneurs imperfectly develop and manage social capital (Maurer and Ebers, 2006) and one set of contacts may be stronger than another (Steier and Greenwood, 2000). This issue has been neglected in the migrant context and may be a particularly salient issue with TEs compared to EEs and REs as they have to manage social capital in two jurisdictions. However, we know little about how TEs use different types of social ties to overcome resource constraints in venture founding. Hence we explore the following research questions in this paper: how do TEs use personal and industry ties in the host and home countries in the founding of their TNVS? How does the nature of prior experience of TEs impact the use of personal and industry ties in the founding of their TNVs?

We explore these questions based on 15 in-depth interviews with TEs of Indian origin in the UK, an important group of entrepreneurs, and nine heads of their transnational operations. Entrepreneurs of South Asian origin in the UK have established a remarkable number of independent businesses since the 1970s (Basu, 1998). Those of Indian origin are increasingly engaging with non-traditional, knowledge-intensive sectors of activity, especially in India (Ram and Jones, 2008), a trend reinforced by recent inflows of highly skilled Indian migrants into the UK and their links with India (McEwan et al., 2005). Whereas in the UK these individuals are enabling a globalisation from below, in India they are making locally available a wide range of managerial, technical and international marketing skills through their ventures (Parthasarathy and Aoyama, 2006). Recent research has recognised the importance of leveraging overseas co-ethnic ties by entrepreneurs in India (Lorenzen and Mudambi, 2013; Prashantham et al., 2015), 
however, there is little understanding of how individuals of Indian origin based abroad use social ties to pursue entrepreneurship in their home country.

We make two contributions to the literature. First, in showing how differences in the nature of prior experience of TEs translate into differences in social ties in the founding of their ventures, our findings extend the migrant entrepreneur literature on the role of social ties in venture creation. Previous research has tended to focus on the role of strong family and ethnic, that is personal, ties for entrepreneurs that make a one-way move from the home country and create ventures within the host country (Cucculelli and Morettini, 2012; Light et al., 2013). Our findings show that industry ties may also be important for entrepreneurs embedded in dual country contexts, and that the relative importance of personal and industry ties is contingent upon the nature of their prior work experience. TEs substitute or complement personal and industry ties based on two dimensions of prior work experience: prior experience of entering the home country, and prior experience of implementing the business opportunity underlying the transnational venture in the home country, respectively, with a former employer. While social ties motivate venture creation, how TEs structure and use their network relationships is contingent on the human capital from their prior experience and gaps in knowledge that they need to fill.

Second, we extend the general entrepreneurship literature relating to the interaction between human and social capital. Prior studies of the relationships between human capital and social capital have mainly focused on the extent and nature of prior start-up or work experience in a single geographic setting (e.g., Davidsson and Honig, 2003; Mosey and Wright, 2007). Unlike prior studies, our findings in the cross-national context of TEs show that where specific human capital, that is, prior experience, was gained, whether in the host or home country, also has a contingent influence on the interaction between human and social capital. More specifically, TEs' prior experience of entering the home country and implementing the business opportunity underlying the transnational venture in the home country, respectively, with a former employer influences their use of social ties in venture founding. In showing where specific experience comes from, and how it interacts with social capital, these findings extend the literature on the difference between specific and general human capital in venture founding to the case of TEs.

\section{TEs, and venture creation in host and home countries}

The importance of space in entrepreneurship in an international context is recognised in studies related to the formation and international expansion of new ventures (Yeung, 2009). The host and home country institutional environments play a significant role in shaping the founding of transnational ventures by TEs (Chen and Tan, 2009; Drori et al., 2009; Terjesen and Elam, 2009). There is broad consensus that although TEs are heterogeneous, hailing from many countries and possessing different motivations and experiences, they act on multiple levels, simultaneously operating in at least two social contexts. Even though not all TEs are migrants (Portes et al., 2002) from developing countries, most operate between host and home countries (Chen and Tan, 2009). These countries may be developed economies, emerging/transition economies, or developed and emerging/transition economies. Exhibiting considerable heterogeneity in the rules of the game for doing business (Hoskisson et al., 2000), developed and developing country contexts, as our focus in this paper, pose pressing constraints arising from differences in 
political, economic and social systems (Drori et al., 2009). TEs founding ventures across these contexts may have to strategise regarding how to leverage government policies related to foreign investment, access knowledge of local rules and regulations, or build relationships with local players including customers, governments or other businesses in order to compete in these markets.

Relative to other types of migrant entrepreneur that cross national borders, TEs are distinctive in their ability to distance themselves from institutional norms and mold host and home institutional environments to accomplish their goals based on a combination of their mindsets and resources (Yeung, 2009). Gained early in life while growing up or later through advanced education, migration, or careers at multinational corporations, TEs have unique experiences that provide knowledge and relationships, and facilitate the development and transfer of resources across host and home countries (Drori et al., 2009).

Although entrepreneurship studies recognise the distinctive features of TEs arising from the interplay of their human and social capital, and host and home country institutional contexts, with few exceptions (e.g., Patel and Conklin, 2010; Terjesen and Elam, 2009), studies on TEs are theoretical in nature. Key themes in TE research include their motivations and typology (Portes et al., 2002) or economic contribution to host and home countries (Wagner et al., 2002). The transnationalism literature is criticised for the relative lack of attention to the impact of states and their intersection with individual resources (Waldinger and Fitzgerald, 2004). In the next section, we turn to the role of prior experience and social ties in venture creation.

\section{Prior experience, social ties and venture creation}

\subsection{Role of human capital in venture creation}

Human capital of entrepreneurs is positively associated with new business formation, entrepreneurial discovery and exploitation (Shane, 2000), and internationalisation (Onkelinx et al., 2015). As important elements of human capital, prior knowledge and work experience facilitate the recognition of market gaps and assessment of opportunities to fill those gaps (Singh, 2000). Individuals with more prior knowledge are more likely to make connections among pre-existing and new ideas, and hence recognise and exploit opportunities (Venkataraman, 1997). Knowledge of specific markets acquired through learning by doing from initial foreign market entry also reduces the perceived uncertainty of market entry, leading to further international commitment (Johanson and Vahlne, 1990).

Human capital derived from prior work experience enables entrepreneurs to build ties with other firms, customers or suppliers, and to improve the effectiveness of the resultant social capital in spotting opportunities ( $\mathrm{Li}$ et al., 2014). International entrepreneurs can draw on the social capital associated with their past ties to obtain market-specific knowledge at low cost that enables them to establish a direct relationship with customers in foreign markets (Sandberg, 2014). Where suitable networks are unavailable, they actively build new connections, sometimes at the idea generation stage, to access information, knowledge and learning in order to enter distant, markets and exploit the opportunities identified (Oviatt and McDougall, 2005). Social networks help overcome resource deficiencies, and founders carefully structure their relationships immediately 
before and during firm-founding to augment their human capital or gain greater access to resources at the time an international opportunity is presented. Although human capital is an important antecedent to social capital, an understanding of how human capital influences the use of social ties that provide social capital in an international context is limited.

\subsection{Role of personal and industry ties in venture creation}

The main premise of social network theory is that economic activity cannot be analysed without consideration of the social context in which it occurs (Aldrich and Zimmer, 1986). Social capital involves the actual and potential resources derived from social networks (Nahapiet and Ghoshal, 1998). Social networks enable entrepreneurs to identify and exploit both domestic (Arenius and De Clercq, 2005) and international opportunities in small and new firms (Prashantham et al., 2015). Social networks substitute formal institutions, especially important in emerging economies such as the Indian context explored here, where many laws and regulations common in developed economies are either absent or poorly developed (Hoskisson et al., 2000). Entrepreneurs entering these economies rely on social networks to cope with uncertainty, acquire legitimacy, and offset the absence of formal institutional support.

The social capital literature distinguishes between personal and industry ties based on the nature of relationships between specific people (Coviello and Munro, 1995). As venture creation by TEs is a boundary spanning activity and TEs are a class of migrant entrepreneur, we build on entrepreneurship and migrant entrepreneurship literatures regarding the role of personal and industry ties in both venture creation and internationalisation. Encouragement from parents, close friends and personal contacts who own businesses is particularly important for influencing entry into (Davidsson and Honig, 2003) and providing information and resources for entrepreneurship (Gartner et al., 1992; Ostgaard and Birley, 1996).

Several studies explore the formation and development of ventures by EEs that start a business in their new country of residence (e.g., Deakins et al., 2007; Portes and Zhou, 1992). At the heart of EEs' social networks are strong family ties (Ram, 1994). Social capital based on strong family ties determines attitudes to entrepreneurship and provides ideas, capital and skills, especially at the time of EEs' entry into the host country (Bagwell, 2007). Personal contacts of EEs in foreign markets also facilitate entry into those markets (Tung and Chung, 2010). As sources of local knowledge, personal ties can be a proxy for social networks, especially for entry into the home country, and especially where the home country institutional environment is less developed and starkly different from the country of residence (Hoskisson et al., 2000). Lorenzen and Mudambi (2013) argue that based on commonalities in language and culture, experience and contacts, decentralised personal ties of highly skilled diaspora in developed economies enable them to start ventures in different clusters. Originating through kinship, friendship or other types of weak ties, personal ties help build 'swift trust' when establishing global linkages or coordinating economic activities between host and home countries (Saxenian, 2005).

Personal ties, however, are fraught with the risk of 'overembeddedness' (Uzzi, 1997). Personal relationships based on family are also unlikely to thrive in situations needing constant infusions of new and diverse knowledge, thus necessitating reliance on outsiders beyond the family (Lorenzen and Mudambi, 2013). Overreliance on the family constrains 
business development of EEs (Deakins et al., 2007). EEs with strong co-ethnic ties tend to be weakly connected with outside agencies, thus missing out on important information.

Industry ties are useful informal sources of information for launching new ventures beyond the family (Ozgen and Baron, 2007). Cucculelli and Morettini (2012) show the heterogeneity in cross border ties and networking activities of Indian software firms in Italy. Saxenian et al. (2002) report that skilled migrant entrepreneurs in Silicon Valley set up business operations in their home country based on developing and capitalising on industry connections. Migrant entrepreneurs having links with former colleagues or venture capital firms are advantaged relative to their mainstream counterparts due to their privileged access to home-based sources of capital, markets, and manufacturing capabilities.

In sum, the importance of personal and industry ties for both venture creation and internationalisation is established in the entrepreneurship literature. The literature on personal ties of migrant entrepreneurs also spans both creation and growth of their ventures. However, evidence typically relates to ventures created at the time of entry into, or within, the host country. Where there is evidence of entry into the home country, it mainly concerns the role of social ties of diasporas in the development of indigenous entrepreneurship at home, location and entry mode choice of internationalising EEs, or resources embedded in networks of REs that return home to found a new venture. The geographic configuration of TEs' networks in the host and home countries likely has a distinct impact on TEs. However, how TEs use social ties in the host and home countries to create a new venture in the home country is not well understood. Unlike EEs that draw on predominantly personal ties to found a venture in the host country and enter other markets to extend existing operations, TEs operate beyond the boundaries of their ethnicity to commercialise a business idea in multiple institutional settings. The nature of TEs' prior experience in these settings may impact the use of personal and industry ties.

\section{Methodology}

A qualitative methodology based on case studies is frequently used in research on social networks (Eisenhardt, 1989), an approach we adopt in this paper. We conducted in-depth interviews with 15 TEs and nine heads of their TNV operations. There is a large volume of literature on venture creation in a single geographic setting, and on migrant entrepreneurs in their host country. In contrast, there is relatively little literature on TEs that create a link with their home country, and simultaneously navigate both host and home countries. Therefore, while existing theory relating to migrant entrepreneurs is informative, it falls short in addressing the role of the different types of social ties and experience in TEs. Accordingly, we adopt an approach of extending theory based on in-depth interviews (Buraway, 1991; Danneels, 2002), rather than undertaking a grounded theory study. As such, we used interviews to generate 'thick knowledge' about the nature of TEs' prior experience and use of social ties in venture founding (Dana and Dana, 2005).

TEs were selected based on theoretical sampling (Yin, 1994). Consistent with our focus, we selected our cases from the population of TEs that entered India. First generation Asian migrants arrived in the UK in the late 1960s and early 1970s from countries such as India, Pakistan, Bangladesh and Sri Lanka (Dhaliwal and Adcroft, 2005). Historically, existing literature on the British Asian community has tended to treat 
various sub-groups as a homogeneous mass (Janjuha-Jivraj and Woods, 2002), and much of the academic literature has been aimed at defining and explaining differences between ethnic minority small firms and those of the general small business community (Ram and Smallbone, 2002). However, the Asian British comprise a number of smaller groups, each with different languages. While many are similar to each other, and often identified as separate by virtue of their religious beliefs, their geographical background can be a very strong divide. There is also a dichotomy between first and second generations in their attitudes to business ownership and willingness to accept support from external agencies (Janjuha-Jivraj and Woods, 2002). While the first generation started up primarily for economic comfort and security for the family through maintaining culture and traditions reminiscent of 'back home', and maintained an intense relationship with their businesses, the second generation are more integrated with their host country, and much less resistant to bringing in outsiders to help (Ram and Jones, 1998). At the same time, however, second generation migrants are influenced by two distinct cultures and recent evidence (e.g., Ram and Smallbone, 2002) suggests no difference between first and second generations in their propensity to access external funding from formal sources at start-up.

We selected only those TEs that were of Indian origin. The contrasting nature of institutional contexts in the UK and India provided a pertinent setting for studying these TEs. We selected both first and second-generation migrants, identified from three networking organisations believed to represent the population of Indian TEs in the UK. We contacted The Indus Entrepreneurs (TiE) London, the UK Chapter of TiE that is currently the world's largest entrepreneurial organisation with over 10,000 members in 20 countries, and UK India Business Council (UKIBC) that has been connecting new (and established) businesses considering their first market entry in India since 1993. Additionally, we approached British India Business Forum (BIBF), an organisation founded relatively recently to raise the profile of British Indian entrepreneurs in the UK. Based on written requests to key administrative personnel at these organisations, we initially identified a total of 39 individuals that agreed to participate in our study. In accordance with Drori et al. (2009), we classified those entrepreneurs as TEs that commercialised a business idea in the UK and India at inception. Based on preliminary interviews, we eliminated 24 founders that ventured into India to extend their business at a later stage in the life of their ventures. The 15 individuals retained were heterogeneous in terms of migration history in the UK, industry sectors, and nature of prior experience in UK and India.

\subsection{Data collection}

The lead author conducted in-depth, face-to-face interviews between January and March 2013. A majority was conducted at the TEs' offices although one TE who lived in India was interviewed in London while visiting at the time of research. The aims and objectives of the research were clearly explained to the TEs first when the meetings were requested, and subsequently during the meetings. A brief interview guide, containing questions about TEs' age, country of birth, educational and professional background, prior work or start-up experience and frequency of travel to India, was designed and administered to the participants. Information about TEs' industry and year of founding TNV was also collected. TEs were probed about their motivations for founding a TNV in India, nature of prior experience and use of social ties in TNV founding. They were asked to reflect on 
how they first conceived the business opportunity, who they approached to validate the idea and acquire information, finance, or first customers for their ventures, and how their personal and professional background and experience influenced venture creation. These questions were developed on the basis of literature related to TEs (e.g., Drori et al., 2009) and role of human and social capital in venture creation (e.g., Davidsson and Honig 2003), and followed up with several sub-questions during the interviews. Interviews were recorded subject to the participants' consent. They ranged from 60 to 120 minutes, and yielded approximately 25 hours of audio recording and 233 running pages of transcripts.

\subsection{Data analysis}

First, interview transcripts were read and re-read to develop detailed case histories of TEs outlining their motivations, personal and professional background in tabular form (Table 1). Next, we coded the data to identify the use of social ties for each TE (Table 2). We classified TEs' ties as personal and industry. Even though different authors use different labels, there is consensus in the entrepreneurship literature that social ties include personal ties such as family and friends (Coviello, 2006; Pruthi, 2014), and industry ties such as former colleagues, suppliers, customers or competitors (Coviello and Munro, 1995). We classified both former colleagues and customers as industry ties because of their industry knowledge and experience. While former colleagues bring industry knowledge based on their experience in the firm (former employer), customers are persons reporting based on their experience in the customer firm. As the entrepreneur epitomises his or her firm and he or she has personally to integrate various social and business dimensions of ties (Johannisson et al., 1994), we included ties between individuals, and between individuals and organisations (O'Donnell et al., 2001). We classified ties as personal or industry based on how respondents interpreted the relationship in the interviews. For example, Case K described his links with former clients (business families in India based on prior experience in advisory role) as 'strong personal'. Therefore, we classified these ties as personal ties. Our classification is outlined in Table 2. As the number of pages of interview transcripts was less than 500, data were manually coded.

Table 1 Brief case histories of Indian TEs in the UK

\begin{tabular}{ll}
\hline Case & \multicolumn{1}{c}{ Personal and professional background } \\
\hline A & $\begin{array}{l}\text { Born in India; migrated to UK with parents at age eight. Family-owned small business } \\
\text { in UK in early years. Joined government service; strong family links based on wife's } \\
\text { family in India. }\end{array}$ \\
B & $\begin{array}{l}\text { Born in UK. Grandfather first went to Africa from India and then to UK in 70s. Father } \\
\text { went to India to study but returned to live in UK with wife. Frequently visited mom's } \\
\text { family in India while growing up. Went to live in India to study with family friend from }\end{array}$ \\
& $\begin{array}{l}\text { UK but returned to UK after nine months. } \\
\text { B }\end{array}$ \\
& $\begin{array}{l}\text { Born in UK; parents migrated to UK from East Africa; mother's family in UK for } \\
\text { mentor and extended family; attended LSE and joined investment bank in UK; left job } \\
\text { after few years to start chain of banks for the rural poor in India. }\end{array}$ \\
D & $\begin{array}{l}\text { Born in India, first migrated to US for work, then followed girlfriend to study and work } \\
\text { in UK; founded venture after MBA degree in UK and extensive relevant work } \\
\text { experience for large public sector policy organisation in UK. }\end{array}$ \\
\hline
\end{tabular}


Table 1 Brief case histories of Indian TEs in the UK (continued)

\begin{tabular}{|c|c|}
\hline Case & Personal and professional background \\
\hline $\mathrm{E}$ & $\begin{array}{l}\text { Born and brought up in UK. Parents migrated to UK from India to establish own } \\
\text { business. Completed degree in chartered accountancy to work for large company. Quit } \\
\text { job due to monotony to found own venture based on provision of office supplies to large } \\
\text { firms. Subsequently went back to work for event management company with plans to } \\
\text { enter the India market and moved to live in India where founded independent venture to } \\
\text { replicate same business idea as at former employer in UK. }\end{array}$ \\
\hline $\mathrm{F}$ & $\begin{array}{l}\text { Born in East Pakistan; first came to live in UK with father who was posted to UK } \\
\text { through Indian Foreign Service. Briefly went back to live in India but permanently } \\
\text { migrated to UK due to father's aspirations to live and educate children in UK. Father, } \\
\text { who set up own venture in UK, a constant inspiration while growing up. Worked as } \\
\text { investment banker after engineering and MBA degrees in UK. }\end{array}$ \\
\hline $\mathrm{G}$ & $\begin{array}{l}\text { Born in UK; mother from Parsi community in India who migrated to live in UK in mid } \\
\text { to late 20s. Spent a lot of time in India growing up due to frequent visits; interned at } \\
\text { hospital in Mumbai; good friends and relatives in India operating there for many years. }\end{array}$ \\
\hline
\end{tabular}

$\mathrm{H} \quad$ Born in India; first entered UK with father who came to study engineering from India; subsequently moved to Iran due to father's work; then went to live in India for two years before returning to live in UK at six years of age. Father an entrepreneur who runs a firm that represents manufacturers of building services equipment in the Middle East. Studied at UCL and LSE and first worked as asset manager for private Indian business family in UK.

I Born and bred in UK; dad has roots in Gujarat but was born in Uganda and lived and studied in Mumbai; mother from Mumbai; both parents doctors who emigrated to UK to work and sponsored close relatives to live in UK; strong influence of parents' achievement motivation and assistance in pulling close family to UK from India and Uganda. Also inspired to set up own ventures by Ugandan Asian businesses in UK; strong family ties in India; frequently visited India each year to spend time with extended family while growing up.

J Born and raised in India. Studied in India and worked at India-based public sector bank for eight years prior to coming to the UK to explore expansion opportunities for employer. Studied market in UK to discover gap in market as different from intended growth plans for India-based bank, but related to business experience in India. Quit job to replicate same business idea in the UK.

K Born in India; first came to UK to work for India-based company; subsequently set up own venture in UK.

L Born in India; arrived in UK to study at boarding school at early age; successful track record of turnarounds at former employers in UK; monetary incentive to become entrepreneur based on prior work experience in UK and economic appeal of India; lived in India/frequently visited India while growing up; desire to make a difference.

M Born in UK but went to India when father set up business there. Studied and lived in India for four years until senior school. Returned to UK to go to University. Worked in UK and went to live in India again in professional life. Returned to UK after spending seven years in first business. Set up new businesses in India whilst in India, and also after return to UK. Investor in 15 different businesses in India. Returned to live in UK for children's education.

$\mathrm{N} \quad$ Born in India; migrated to UK with husband; general partner in NHS practice; set up venture to replicate NHS model in India

O Born in Kenya; grandfather migrated to Africa from India; father came to UK in 1970 s. First visited India relatively late in life in 1994. 
Table 2 Role of personal and industry ties in venture creation by Indian TEs in UK

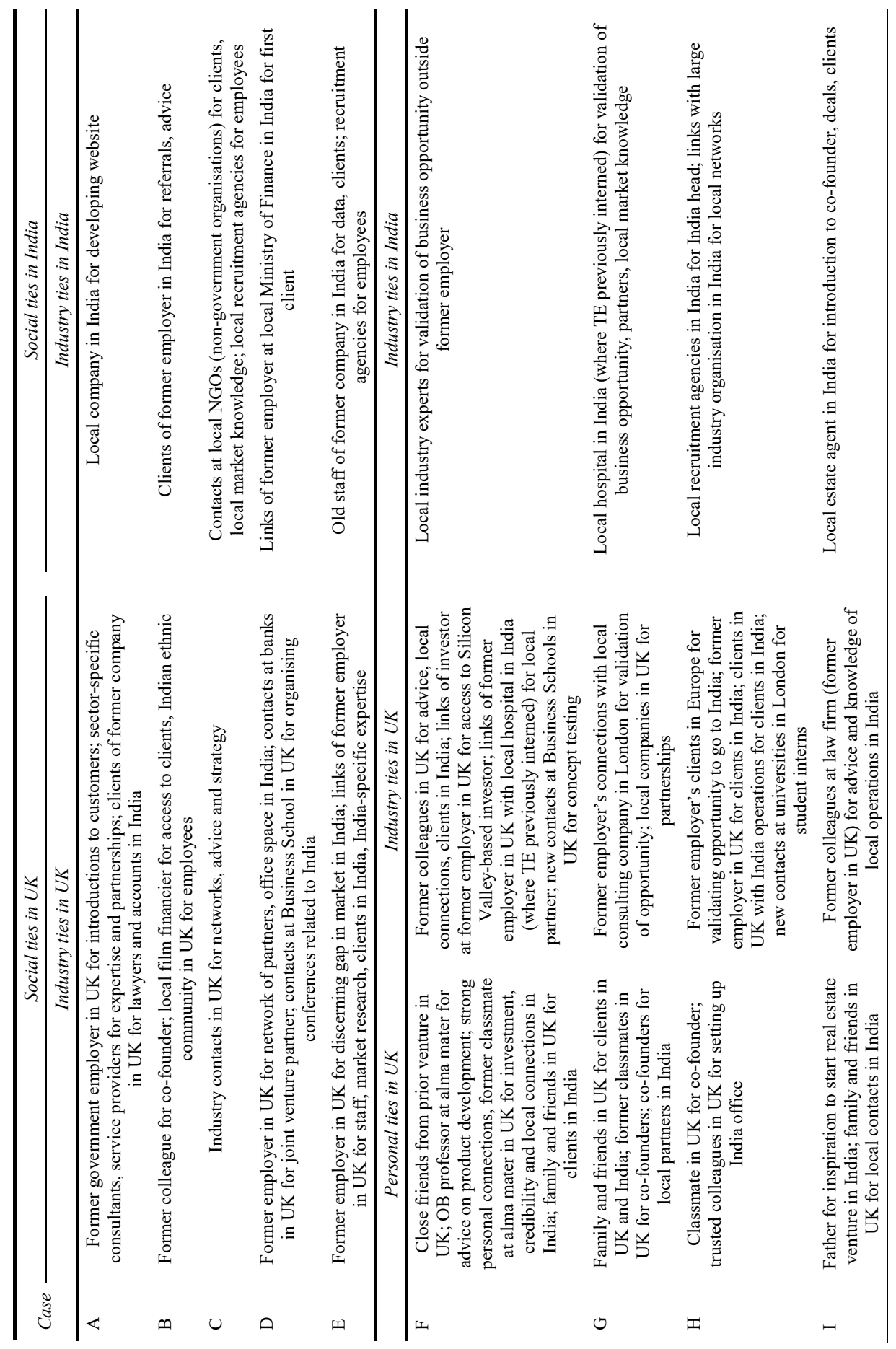


Table 2 Role of personal and industry ties in venture creation by Indian TEs in UK (continued)

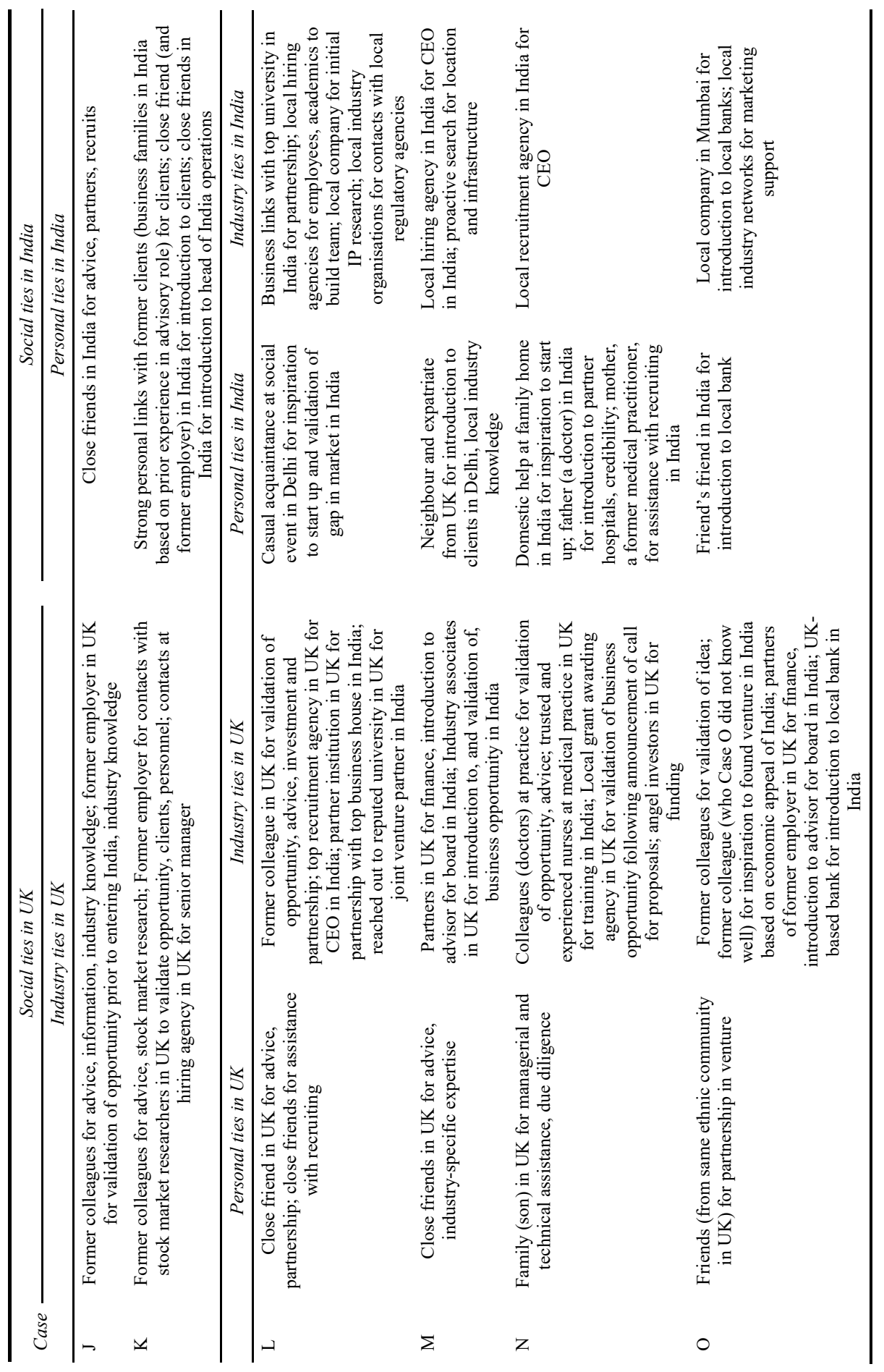


Table 3 Indian TEs in UK

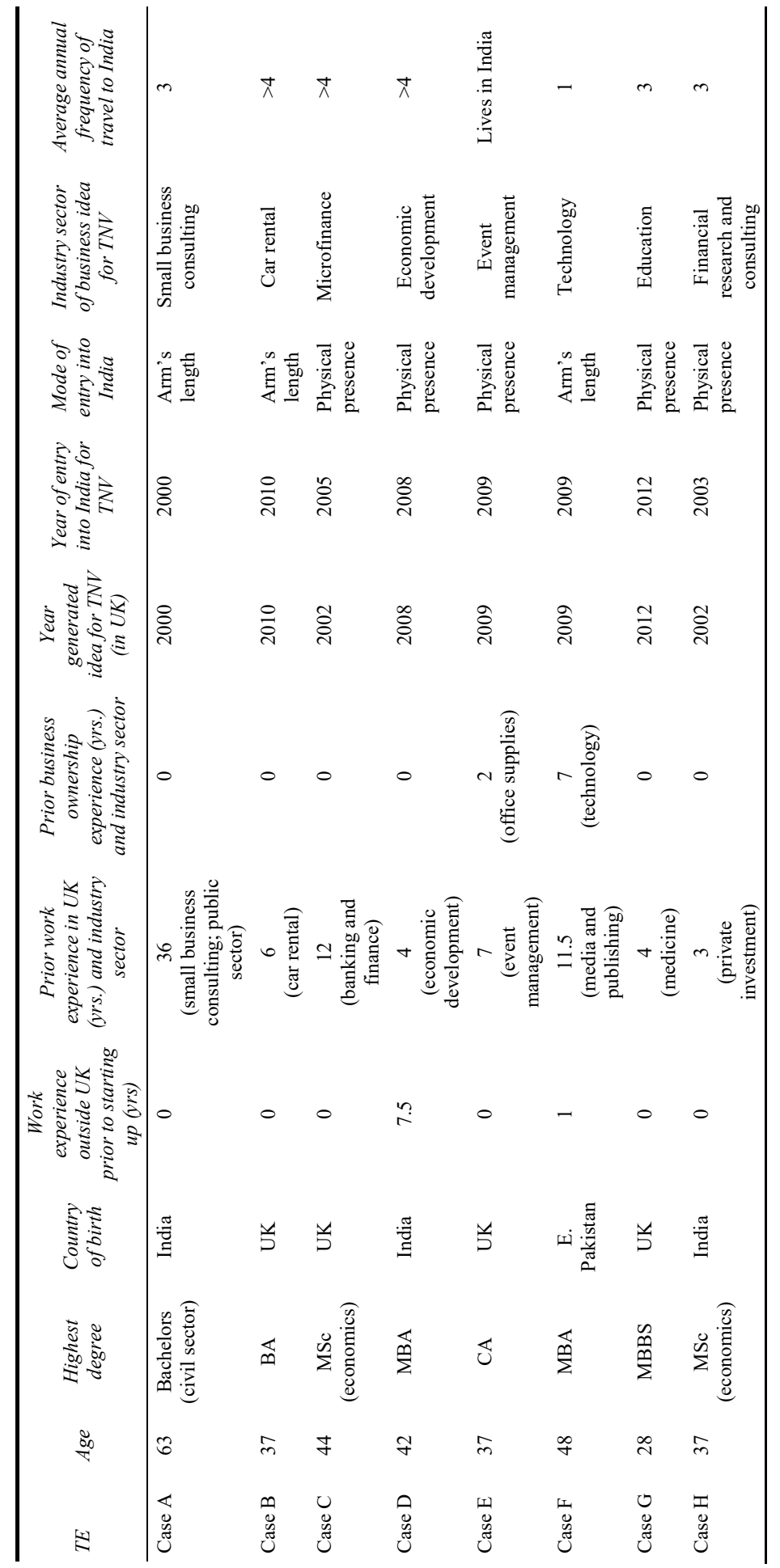


Table 3 Indian TEs in UK (continued)

\begin{tabular}{|c|c|c|c|c|c|c|c|}
\hline 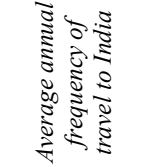 & 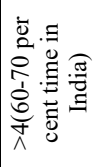 & $\stackrel{+}{\Lambda}$ & $\stackrel{+}{\wedge}$ & ナ & $\stackrel{\lambda}{\lambda}$ & - & $m$ \\
\hline 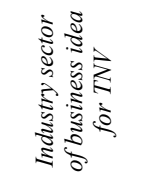 & 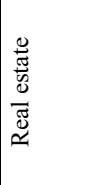 & 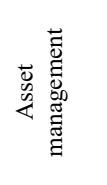 & 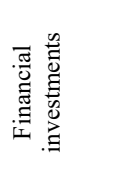 & 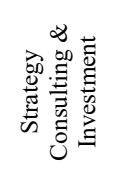 & 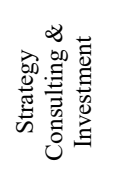 & 总 & 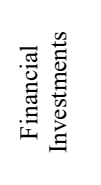 \\
\hline 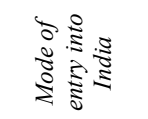 & 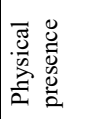 & 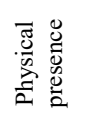 & 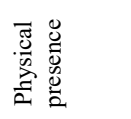 & 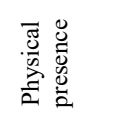 & 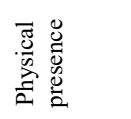 & 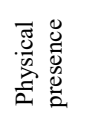 & 夏莺 \\
\hline 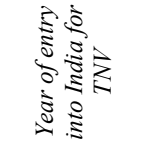 & $\hat{\stackrel{े}{े}}$ & $\stackrel{\sim}{\stackrel{\sim}{े}}$ & 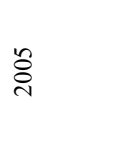 & 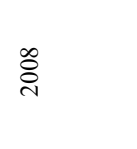 & ڤ్ & 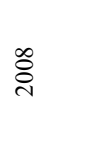 & ષ્ণ \\
\hline 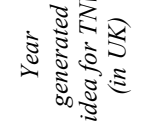 & 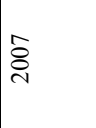 & $\stackrel{\circ}{\stackrel{\mathrm{N}}{2}}$ & ๙ิે & ڤั & ڤి & 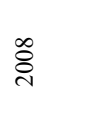 & ષั \\
\hline 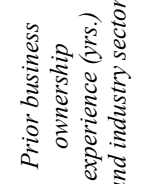 & 0 & 0 & 0 & 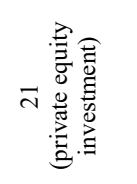 & 0 & 0 & 0 \\
\hline 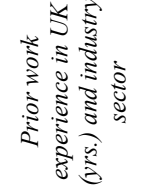 & 을 & 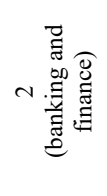 & 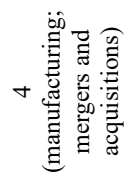 & 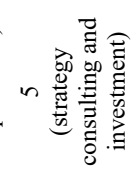 & 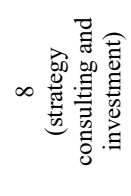 & 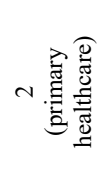 & 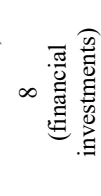 \\
\hline 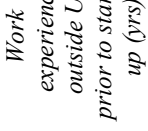 & 0 & $\circ$ & $\infty$ & 0 & 0 & $m$ & 0 \\
\hline อ & $\breve{5}$ & $\stackrel{g}{\exists}$ & $\stackrel{\widetilde{g}}{\Xi}$ & : & 光 & $\stackrel{\frac{\pi}{\sigma}}{\Xi}$ & 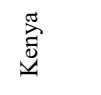 \\
\hline 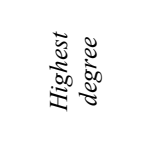 & 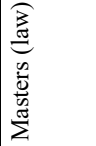 & $\overleftrightarrow{\text { m }}$ & 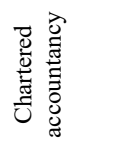 & $\overleftrightarrow{m}$ & 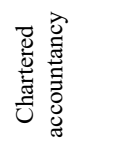 & $\begin{array}{l}n \\
\stackrel{n}{\Sigma}\end{array}$ & 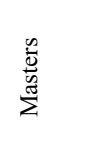 \\
\hline$\$$ & ले & テ & $\stackrel{\infty}{+}$ & in & $\ddot{f}$ & $n$ & in \\
\hline$\underline{N}$ & $\begin{array}{l}\overrightarrow{0} \\
\tilde{z} \\
\tilde{J}\end{array}$ & $\begin{array}{l}\tilde{0} \\
\tilde{J} \\
\tilde{J}\end{array}$ & $\begin{array}{l}\qquad y \\
u \\
\tilde{z} \\
\tilde{J}\end{array}$ & $\begin{array}{l}\overrightarrow{0} \\
\tilde{J} \\
\tilde{J}\end{array}$ & $\begin{array}{l}\sum_{0} \\
0 \\
\tilde{J} \\
\tilde{J}\end{array}$ & $\begin{array}{l}z \\
0 \\
\tilde{z} \\
\tilde{z}\end{array}$ & $\begin{array}{l}0 \\
0 \\
\tilde{J} \\
\tilde{J}\end{array}$ \\
\hline
\end{tabular}


Table 4 Country heads of Indian TEs in UK $(\mathrm{N}=9)$

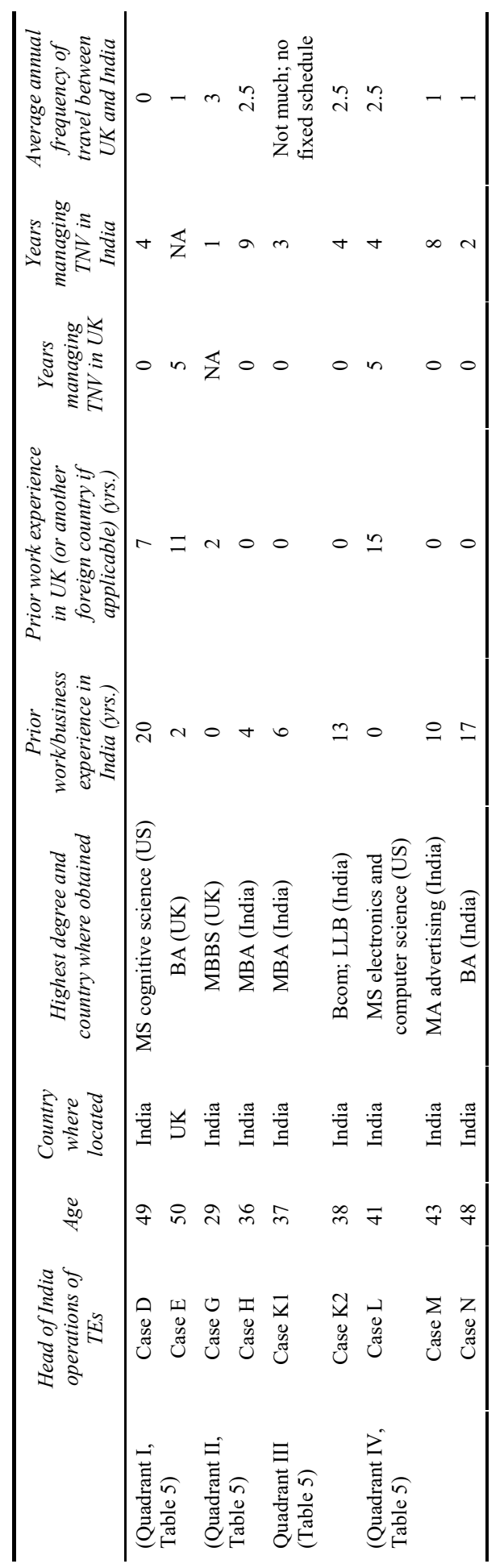


Similarities and differences in the role of social ties across groups of TEs in the sample were established in an iterative manner based on the constant comparative method of data collection and analysis, analysing data obtained from each case simultaneously with collection, and moving back and forth between data and literature (Suddaby, 2010). A data display with arrows was developed early in the analysis to consider the temporal sequence of venture founding activities based on TEs' motivations and nature of prior experience in the UK and/or India. Two broad types of TEs emerged, those that had prior experience of entering India with a former employer, and those that had no such experience. Use of social ties in the generation and validation of the business opportunity and acquisition of resources in the UK and India was mapped for these TEs based on information provided in the interviews. As data collection and analysis progressed, heterogeneity of TEs based on three other dimensions, namely, timing of migration to the UK, prior entrepreneurial experience in the UK or India, and prior experience of implementing the business opportunity in India with a former employer, was identified. We developed matrices using a combination of these dimensions, re-ordering cases in various ways to assess their fit and identify patterns in the use of social ties.

In several cases, interviewees were contacted again to fill gaps in interview transcripts. Secondary sources of information such as company reports, websites and press releases were also used to verify the insights obtained from the interviews where possible. Subsequent to the UK interviews, nine counterparts of TEs (Cases D, E, G, H, $\mathrm{K}, \mathrm{L}, \mathrm{M}$ and $\mathrm{N}$ ) with a physical presence in India at the time of research were interviewed between June and August 2013. Two heads each (D and E; G and H; two India heads of Case $\mathrm{K})$ in three quadrants of the matrix, and three $(\mathrm{L}, \mathrm{M}, \mathrm{N})$ in one quadrant, were reached. For Case E who lived in India at the time of the research, his country head in UK was interviewed in London. All other interviews were conducted in India. The interviewees were probed about when and how they first came in contact with the TEs, and their role in the TNVs. These interviews were important for validating TEs' account of venture founding based on their managers' role in this process, and triangulating the nature of TEs' social ties in acquiring resources (India managers) in venture founding. The co-author, who was distanced from the data collection process to avoid confirmatory biases, was shown all transcripts and periodically consulted to check the validity of the emerging insights.

Tables 3 and 4 present a description of our cases in the UK and heads of their India operations, respectively. The interviewees were 46 years old on average, with the youngest 28 and the oldest 63 years old at the time of the research. All interviewees except one had a master's degree. Seven were born in India, one in Kenya, one in East Pakistan, and six in the UK. On average, the TEs had 8.16 years' prior work experience in the UK, and two years outside of the UK, prior to starting up. Three TEs (Cases E, F and L) had previously founded a venture in the UK, the length of their prior start-up experience being two, seven and 21 years, respectively. Five had founded their TNV in India in the last five years at the time of research. Eleven had a physical presence in India where they had established an office for the conduct of their business, whereas four were in the early stages of founding their TNV. Except Case E who had moved to India to set up the business at the time of this research, all others lived in the UK and travelled to India, with eight of the $15 \mathrm{TEs}$ travelling as frequently as four times a year. The country heads of TEs were 41.1 years old on average with the youngest 29 and the oldest 50 years old (Table 4). Eight were located in India, whereas one was based in the UK. On average, these individuals had eight years' prior work experience in India and 4.1 years in the UK 
before managing this TNV. The individuals in India had managed the venture for 4.85 years on average; the individual in the UK had managed the venture for five years.

The TEs cited emotional reasons such as desire to 'make a difference' [Cases D, J], 'do good' [Case C] or enable India to play an important role in their global plans for business due to their personal heritage or strong cultural affinity with India [Cases A, E, $\mathrm{J}, \mathrm{K}]$ as the key motivations for creating a TNV in India. Monetary incentives based on the economic appeal of India [Cases D, M], perceived gap in the market [Case J, L] or need to exploit advantages of talent and low cost [Case $\mathrm{K}]$ were also cited as important.

\section{Findings}

Four broad patterns emerged in the use of social ties based on whether TEs had prior experience of:

a entering India

b implementing the business opportunity underlying the TNV in India, respectively, with a former employer (Figure 1).

Cases A to I formerly worked in India with a former employer in the UK, while Cases J to $\mathrm{O}$ had not formerly entered India with a former employer (Cases $\mathrm{J}$ and $\mathrm{K}$ decided to create an independent venture after first arriving in the UK as expatriates of an India-based company, whereas Cases $\mathrm{L}, \mathrm{M}, \mathrm{N}, \mathrm{O}$ had no prior experience of working in India). Cases A, B, C, D, E, J, K replicated the same business idea for their TNV as they had previously implemented in India for a former employer, but Cases F, G, H, I, L, M, $\mathrm{N}, \mathrm{O}$ exploited a perceived market gap unrelated to their prior work experience in India.

\subsection{Industry ties substitute for lack of personal ties in UK and India}

All TEs in this group did not have a business idea for a TNV prior to working in India. They first identified the idea through work experience in India with a former employer in the UK, and validated it with former colleagues, clients or local government links developed in India through the former employer. In addition, they sought new industry ties based on conferences or Indian networking organisations in the UK, outside of the former employer in India, to validate the idea and acquire advice or customers.

As an illustration, Case C, who frequently travelled to India as head of the capital markets team for Asia at a UK-based large bank, had not thought of founding his own venture prior to working in India. He decided to set up a microfinance venture in India outside of his former company to exploit connections with local clients developed during his work stint in India: “...I started in computers and then banking, and banking allowed me then to go to India and do banking ... if my banking experience did not exist I am not sure I would have done this" [Case C]. Case E, who had previously co-founded (and subsequently closed) a business in the area of office supplies in the UK, said he knew he would start an event management company in India after being made redundant by his former employer that decided to close their India operations in the same business: "Yeah I did have the idea that when I got made redundant [at former company in UK] I still want to go to India, so I will do my own thing" [Case E]. 
Figure 1 Structural categorisation of prior experience and social ties in venture creation by Indian TEs in the UK

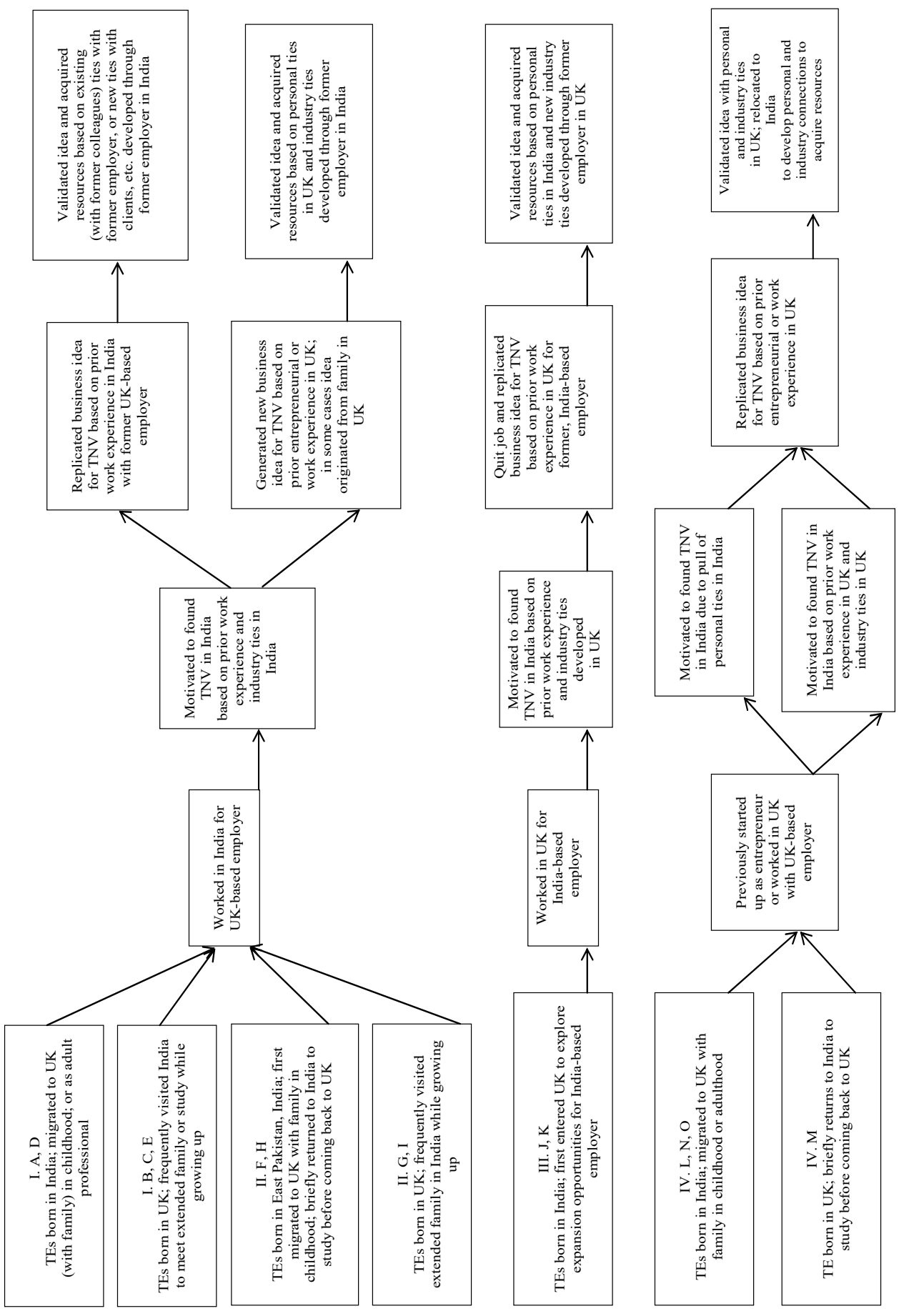


Prior work experience in India and connections with former colleagues, clients or local government developed in India through the former employer helped validate the business idea for the TNV. These ties also provided local market knowledge, and access to customers for the business in some cases. For Case D, for example, the first opportunity to enter India was a call from the local government that he had established a link with during his prior work experience in India: “...so the first break came with XXX [ministry in India] ... I obviously knew them from my YYY [former company] days [in UK]. So they invited us along with ZZZ [development bank in Asia] to develop a whole new policy framework for the waste sector in the country [India]...that created an entry point for us" [Case D].

Even though the idea for the TNV was based on prior work experience in India, seeking new ties both in the UK and India was important to gaining the confidence to go there for business and further validating the business idea. Whereas Case A developed 'very strong links' with Indian industry organisations and universities in the UK for organising trade delegations to India, Case D organised several conferences at his former academic institution that connected him to new industry associates in India and instilled the confidence to go there for business. Case D explained that although the links he had cultivated through his former company in the UK were useful, he needed a 'permanent container' within which to place his idea and engage in networking outside of his former company in order to start up: "So it was...essentially my idea from XXX [former company] but ... I needed something, a permanent container ... the first 12 to 18 months was just going out and doing the networking ..." [Case D].

These TEs also cultivated new, industry ties in India. Case A said he established his own network of contacts outside of the employer in India: “... but we've also established our own network of contacts... whether its legal firms, you know law firms in India or err, accountancy firms or whatever it might be ..." [Case A]. Case C spent one year in rural India to do market research and build new contacts to help him validate the demand for rural banking in India. He argued that even though he knew banking based on his prior work experience, the process gave him a new perspective on how to do it: "...the only thing I knew as a product was banking. So I started looking at how I can deliver banking services and products to, those at the bottom of the pyramid in India...so I spent, 2006 doing a lot of desktop research ... I spent 2007 in rural India working with some NGOs, helping understand their business model. And I spent about a year in urban India doing exactly the same in Mumbai ... and then I came up with a new idea on how to do it." [Case C].

These TEs did not perceive personal ties in India to be valuable in founding their TNV. For some, family in India were not believed to be relevant to the business; in other cases, family members were overwhelmed by what the TEs were trying to accomplish. For example, Case A said that his relatives in India were more interested in using their relationship to gain an entry into the UK, rather than helping him establish a venture in India. For Case D, his parents remained unconvinced about the merits of the business idea and hence his ability to successfully execute it. Therefore, industry ties established through the former, UK-based employer became invaluable. As Case D's India manager confirmed, he met Case D through an India-based friend who knew Case D through his business links in the UK: "I think I don't know XXX [Case D] no no this common friend we had he brought us together so and then we just started off ... yes he is based out of India, I think he was in India and he used partner in UK ... and he said you got to meet 
XXX [Case D] and XXX was in Commonwealth and he is highly innovative so we worked together..." [Case D, India Manager].

\subsection{Personal ties in UK complement industry ties in India}

Based on prior experience of doing business in India with a former employer, the industry ties these TEs established in India motivated them to enter India for their own venture. However, the business idea for the TNV was different from that previously implemented in India for their former employer. In some cases, TEs decided to implement an idea they discovered in the UK prior to their work stint in India, whereas in other cases, the idea originated from within the family in the UK. In either case, these TEs drew on industry ties based on prior work experience in India to validate the idea and access local market knowledge to implement it. They also combined previously established industry ties with personal ties including family, former professors or classmates in the UK to validate the idea for their venture. In many cases, personal ties also provided referrals to industry ties in the UK.

Case F, who had prior experience of setting up a media and publishing business in India for his former employer in the UK, recalled how he previously experienced the problem of identifying key performers on a team in his capacity as founder of another business in the UK, however, even though he had had the idea for a long time, he did not have the confidence to execute it. Therefore, following his work stint in India with the media and publishing house, he phoned his former colleagues in India to validate the idea and convert it into an opportunity. Similarly, Case I called former colleagues at his law firm in India to gauge the nature of the local institutional environment prior to establishing a venture in the real estate industry, an idea he decided to execute based on his knowledge and experience as a lawyer: “...the regulatory side of India is tough because the rules have kept changing ... and I think that's where my experience has been invaluable ... and actually most of the big law firms I've worked with in India and I know the partners, and I've been able to sort of say hi ... I want to come and see you" [Case I].

These TEs also cultivated new industry ties outside of the former employer. New ties were important to obtaining local market knowledge or accessing potential recruits, partners or customers. Case $G$, for example, actively searched for local experts in the industry in India to validate his business idea prior to starting up: “... we went out to Mumbai and Bangalore for two to three weeks initially. And we literally just had meetings from morning to evening with different companies" [Case G].

A common theme that emerged from the interviews was the role of family in the UK in venture creation for these TEs. Case F recalled how his wife's cousins and their connections with a large UK bank helped him run a pilot study to test the business idea prior to venturing into India: “... My wife has a very large extended family in the UK and actually globally ... and one of them who is a XXX [Business School in US] alumnus...introduced me to one of his former colleagues ... XXX will be doing a pilot with me shortly ... so through the family association" [Case F]. Case G considered his co-founders' parents to be his mentors who actively advised him in the venture creation process: "I'd like to say our parents are our mentors actually to be honest with you. X's [co-founder 1] dad is a very successful business man himself, Y's [co-founder 2] dad as well had a very successful career in advertising so I think we very much, thankful for the help that they provided us" [Case G]. 
In other cases such as Case I, the business idea for the TNV originated from the family. Case I then consciously leveraged his work experience at the law firm he worked for to develop his business knowledge of India, and eventually quit his job to enter India based on his father's guidance and connections in the real estate industry in the two countries: "I was concentrating on work and my career as a lawyer. Dad said look you've really got a knack for this [real estate], you should apply some of your knowledge now you're a lawyer, you've got experience with how they do transactions and maybe we can do some real estate stuff in Mumbai" [Case I].

\subsection{Industry ties in UK complement personal ties in India}

The TEs in this category worked with an India-based company in India before coming to the UK to explore growth opportunities for their employers and then quit employment to pursue the same business for themselves, a gap in the market they perceived upon coming to the UK. These TEs reached out to industry ties cultivated at their former employer in the UK to validate their idea. Subsequently, they leveraged personal ties in India based on their prior experience of living and working in India, to validate the idea and acquire resources to implement it.

Case K, who first came to the UK to do acquisitions of manufacturing firms for a large Indian corporation, studied the stock market to get a sense of the nature of private investment in various large and small companies in the UK. Based on advice from former colleagues in the UK, he set up an independent venture to formally advise small firms in the UK, and leveraged close relationships with business families in India to validate his idea: "I have a very strong equity back in India ... so I discussed it with everyone in Bombay, you know this ... opportunity" [Case K]. These families, who he had worked closely with in his capacity as accountant for his former employer in India, were in the process of raising money from the capital market in the UK and validated the opportunity for a financial investment venture in India.

These TEs also cultivated new, industry ties or undertook additional market research in the UK to validate the business idea. In addition to using existing industry ties with clients or suppliers in the UK based on their prior work experience, they attended networking events in the UK and sought student interns to work for them as they bootstrapped their venture.

\subsection{Personal and industry ties in UK complement personal and industry ties in India}

With no prior experience of entering India through a former employer in the UK, these TEs perceived a business opportunity in India based on industry ties in the UK or personal ties in India. In either case, they decided to enter India to replicate a business they were intimately familiar with based on their prior entrepreneurial or work experience in the UK. Where they were motivated to enter India due to personal ties, they consulted with industry ties in the UK to validate the idea or access finance, guidance or even partnerships for their ventures. Those motivated by industry ties in the UK were the ones that did not have any personal connections in India; they went to live in India to develop the relevant connections. Others went to live in India to build industry connections. 
Case $\mathrm{M}$ first decided to venture into India after being approached by a group of industry associates in the UK to set up outsourcing operations outside of the UK. "...I was approached by a number of individuals [in the UK] who were setting up a new call centre business. And I joined them as one of the founders ... and then I went to investigate opportunities to setting the business up in India ..." [Case M]. Cases L and N first perceived an opportunity to do business in India based on their personal ties in India. Subsequently, they validated the idea through former colleagues in the UK. For example, Case $\mathrm{N}$ first conceived the business idea after a casual conversation with a domestic help in India who underwent the trauma of unnecessary diagnostic tests after suffering an accident at home: "At our family farm in XXX [India], one of the farmer's wives was ill, she had a fall, she was pregnant at the time and they were doing lots of irrelevant things...like sending her for scans, lots of follow ups that sort of thing... so we saw the merits of the [primary healthcare] structure [in the UK] and how it could be applied [to India]" [Case N].

These TEs decided to put their plans into action after validating the idea with close friends and colleagues in the UK. Thereafter, they built new contacts in India, in some cases, even relocating to India to penetrate the local network and build new personal or industry connections. Case M, for example, went to live in India to develop the relevant networks: “...Being a Brit and I had no family relationships in Delhi, nothing, I was, in fact the only thing apart from the colour of my skin, I could have been a Brit. But the network in Delhi is very powerful ... in India, you know once you're inside the network it is very easy to make connections and meet people" [Case M]. Case N's parents in India helped her access people and space for her venture. Subsequently, she went to live in India to build relevant industry connections.

Case L spoke with a former colleague and dean of a top business school in the UK who he had closely worked with during his career as entrepreneur and private equity investor in the past. This colleague provided advice, and also partnered with Case L to implement his idea to commercialise technology in India. “...Do you know that came about because they [top business school in London] had a pro rector called YYY. YYY and I had met at some place ... and I remembered him, and I just rang him and said, let's go for coffee and he said sure ... So I talked to a bunch of people and then I, spoke to YYY and, err, yeah said this is what I want to do and I think XXX is a good partner. And he said I think XXX would love to do it with you" [Case L]. Case L's India CEO confirmed how he found out about Case L through a recruitment agency Case L used to advertise the position in the UK: “...I was looking to come back to India....and I was in that group when they started to figure out how to make technology go from lab to market ... so he [Case L] had hired this agency ... they had together put some write-ups somewhere on the web that they were trying to do something of this type. I think they had done a press release saying they wanted to do such technology commercialisation type of an affidavit in India. And I came across that work, and I traced that back to find out who is XXX [Case L] is and learnt about what he was doing" [Case L, India manager].

\section{Discussion}

Our objective was to explore the way TEs use social ties in the founding of TNVs in the home country and whether the nature of prior experience is influential in the use of social ties. Our findings provide novel insights by showing that the heterogeneity in how TEs 
use personal and industry ties in the host and home countries is contingent on whether TEs have prior experience of:

a entering the home country

b implementing the business opportunity underlying the TNV in the home country, respectively, with a former employer.

Our findings show four distinct patterns in TEs' use of personal and industry ties in the host and home countries based on these two aspects of prior work experience (Table 5).

Where TEs have prior experience of entering India with a former employer in the UK, industry ties in India motivate TNV creation (Quadrant I, Table 5). TEs overcome the liabilities of newness related to both new venture creation and home country entry through industry ties in the UK, and industry ties in India where they found a TNV based on the same business opportunity previously implemented in India for their former employer in the UK. These TEs substitute industry ties for the lack of personal ties in the UK and India.

In contrast, where TEs have prior experience of entering India with a former employer in the UK, but found a TNV based on a business idea they have not previously implemented in India with a former employer, they combine industry ties in India with personal ties in the UK (Quadrant II, Table 5). Even though these TEs build industry ties through prior work experience in India, family ties in the UK are vital either for identifying the business opportunity, validating it or providing start-up capital or advice to implement it.

Table 5 Use of personal and industry ties by TEs in venture creation in host and home countries

\begin{tabular}{|c|c|c|}
\hline & Industry ties in host country (UK) & Personal ties in host country (UK) \\
\hline \multirow{2}{*}{$\begin{array}{l}\text { Industry ties in } \\
\text { home country } \\
\text { (India) }\end{array}$} & Quadrant I & Quadrant II \\
\hline & $\begin{array}{l}\text { Industry ties in UK and India } \\
\text { substitute for lack of personal ties } \\
\text { when TEs have prior experience of } \\
\text { entering India with former employer } \\
\text { in UK and prior experience of } \\
\text { implementing business opportunity } \\
\text { in India with former employer }\end{array}$ & $\begin{array}{l}\text { Personal ties in UK complement } \\
\text { industry ties in India when TEs have } \\
\text { prior experience of entering India } \\
\text { with former employer in UK but no } \\
\text { prior experience of implementing } \\
\text { business opportunity in India with } \\
\text { former employer }\end{array}$ \\
\hline \multirow{3}{*}{$\begin{array}{l}\text { Personal ties in } \\
\text { home country } \\
\text { (India) }\end{array}$} & Quadrant III & Quadrant IV \\
\hline & $\begin{array}{l}\text { Industry ties in UK complement } \\
\text { personal ties in India when TEs have } \\
\text { prior experience of implementing }\end{array}$ & $\begin{array}{l}\text { No evidence of complementarity of } \\
\text { personal ties in UK with personal ties } \\
\text { in India; }\end{array}$ \\
\hline & $\begin{array}{l}\text { business opportunity in India with } \\
\text { former employer but no prior } \\
\text { experience of entering India with } \\
\text { former employer in UK }\end{array}$ & $\begin{array}{l}\text { Personal and industry ties in UK } \\
\text { complement personal and industry } \\
\text { ties in India when TEs have no prior } \\
\text { experience of entering India with } \\
\text { former employer in UK or } \\
\text { implementing business opportunity in } \\
\text { India with former employer }\end{array}$ \\
\hline
\end{tabular}


Table 6 Examples of influence of social ties on TNV performance

\begin{tabular}{|c|c|c|}
\hline 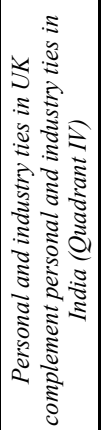 & 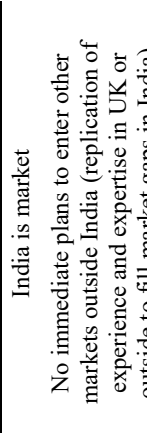 & 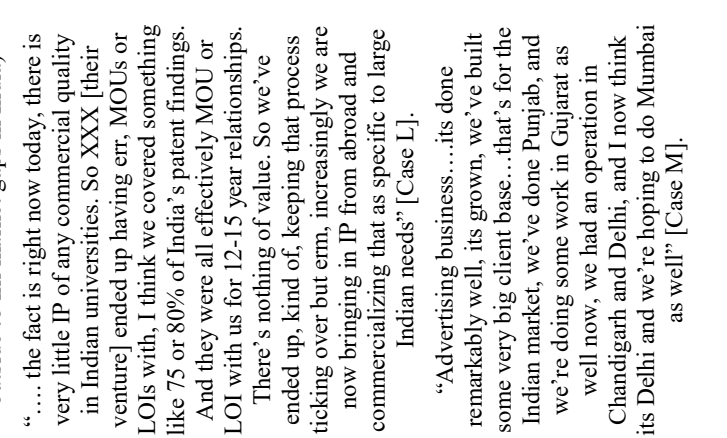 \\
\hline 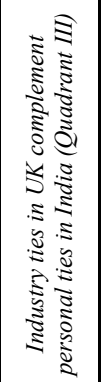 & 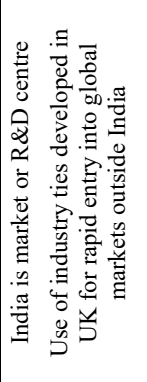 & 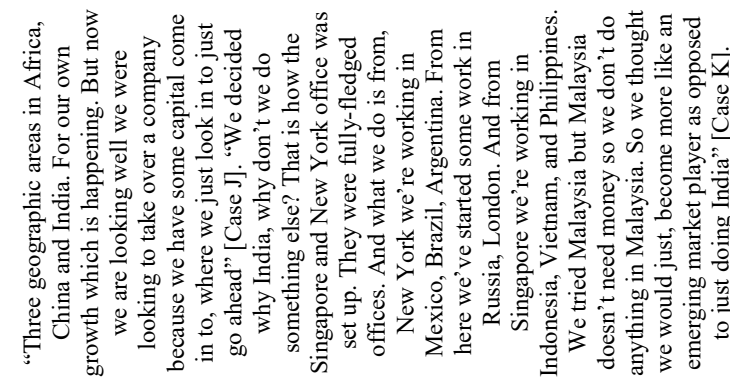 \\
\hline 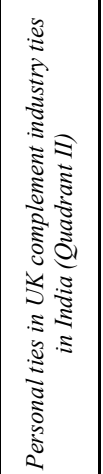 & 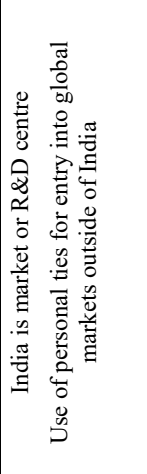 & 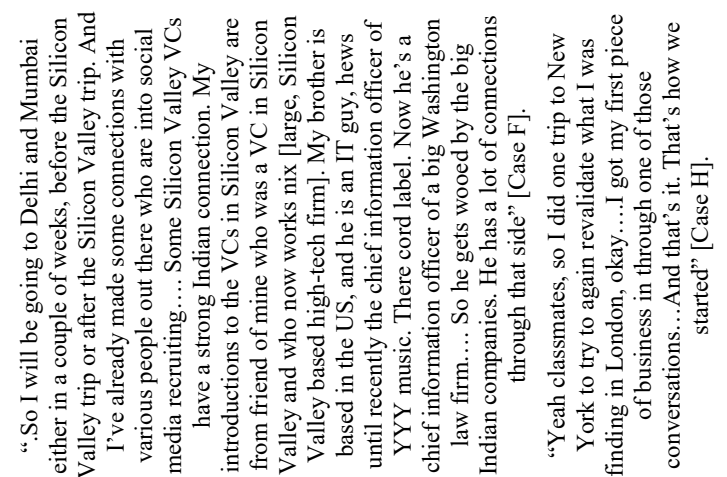 \\
\hline $\bar{z}: \bar{z}$ & 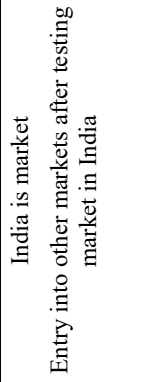 & 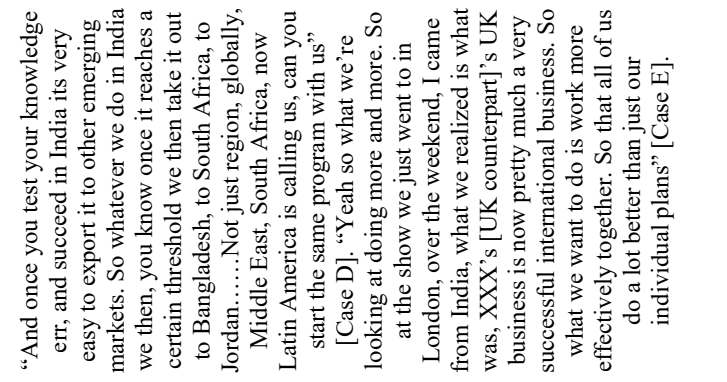 \\
\hline & 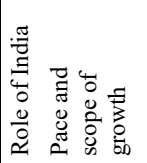 & $\frac{8}{8}$ \\
\hline
\end{tabular}


Where TEs have prior experience of working in India with a former employer in India before going to the UK, industry ties developed in the UK through the former employer motivate the creation of a TNV (Quadrant III, Table 5). These TEs also draw on personal ties cultivated in India prior to going to the UK to validate their idea or access advice for their TNV. They complement industry ties in the UK with personal ties in India.

TEs in the fourth category do not have any prior experience of either working in India or implementing the business idea underlying the TNV in India with a former employer; they found a venture based on an idea they have previously implemented in the UK. In some cases, they are motivated to establish a business link with India due to the pull of personal ties in India; in other cases, they are led into India due to industry ties in the UK. In some cases, these TEs even relocate to India to develop relevant personal or industry connections. They combine personal and industry ties in the UK with personal and industry ties in India. These findings help extend the traditional migrant literature by showing that personal ties alone (Quadrant IV, Table 5) are not sufficient for transnational venture founding. When TEs have no prior experience of entering the home country or implementing the business opportunity at home with a former employer, and hence lack personal ties, they search for relevant industry connections based on prior work or entrepreneurial experience in the host country or build new industry ties at home to validate the business opportunity or access resources for their TNV. These findings corroborate prior research on the limitations of personal relationships and hence the need to go beyond friends and family to access more diverse knowledge in venture founding (Lorenzen and Mudambi, 2013). Further research might usefully explore the contingent nature of the relationship between human capital from prior experience and use of social ties in other migrant entrepreneur contexts.

These findings contribute to the literature in two main ways. First, we extend the migrant entrepreneurship literature on the role of social ties in new venture creation. An established stream of literature (e.g., Light et al., 2013) explores the role of personal or ethnic ties in venture founding by EEs, mainly in their new country of residence. Where entrepreneurs' connections in both host and home countries are explored, they are mainly in the context of internationalising EEs that extend their firms to the home country (Chung and Tung, 2013) or REs that draw on their connections abroad to found new ventures upon returning home (Pruthi, 2014; Wadhwa et al., 2011). TEs are different because they are embedded in multiple institutional environments and go beyond ethnic ties to use social ties in both host and home countries at the time of venture founding. With few exceptions (e.g., Bagwell, 2007), however, studies on TEs that originate as migrants in developed countries (e.g., Saxenian, 2003, 2005) mainly highlight the role of their human capital for motivating transnational entrepreneurship or contributing to economic development in host and home countries (Portes et al., 2002). Personal connections of diaspora entrepreneurs are explored in the context of knowledge spillovers and development of entrepreneurship in local clusters in the home country (Lewin and Zhong, 2013; Lorenzen and Mudambi, 2013).

In exploring the role of social ties in venture creation in the host and home countries by TEs, we extend the migrant entrepreneurship literature by showing that how network relationships are structured and used is contingent on entrepreneurs' prior experience and gaps in knowledge that they need to fill. More specifically, TEs substitute or complement personal and industry ties based on two dimensions of prior work experience: prior experience of entering the home country, and prior experience of implementing the 
business opportunity underlying the transnational venture in the home country, respectively, with a former employer. Where TEs have previously entered the home country with a former employer and previously implemented the business idea for that employer, for instance, they have prior knowledge of both entering the home country and implementing the business idea at home, respectively, and mainly draw on industry ties developed through the former employer in the host and home countries in the founding of their TNV; however, where they have no prior experience of implementing the business idea at home even when they have previously entered there with an employer, they use personal ties in the host country in addition to industry ties at the former company to gain knowledge about the viability of the idea or how it can be implemented.

Second, we extend prior studies on the interaction between human and social capital in venture creation in the entrepreneurship literature. Even though human capital is an important antecedent to social capital, an understanding of how human capital influences the use of social ties that provide social capital in an international context is limited. Although prior experience of different types of entrepreneurs has been investigated, these studies mainly focus on nascent (Davidsson and Honig, 2003), academic (Mosey and Wright, 2007) or high technology (Wright et al., 2007) entrepreneurs in a single geographic setting. In our focus on the 'where' of prior experience of TEs as a class of migrant entrepreneur that traverses geographic boundaries, we contribute to this literature. Our findings suggest that the nature of prior work experience in the host or home countries has implications for the structure of TEs' social ties in venture founding in the host and home countries as compared to prior experience among different types of entrepreneurs in a single geographic setting. Where TEs have previously entered the home country and implemented the business opportunity in the home country, respectively with a former employer, for instance, they mainly draw on industry ties developed through the former employer in the founding of their TNV; however, where they have no prior experience of implementing the business opportunity at home even when they have previously entered there with an employer, they combine industry ties at the former company in the home country with personal ties in the host country to gain knowledge about the viability of the idea or how it can be implemented.

The importance of accessing knowledge from social networks to fill gaps in knowledge resonates with prior limited evidence on TEs, which suggests that TEs broaden their network scope to obtain greater access to human capital of participants, and hence increase returns in the conduct of transnational activities (Patel and Conklin, 2010). However, our findings build on these insights by showing how TEs use personal and industry ties to fill gaps in knowledge in the founding of transnational ventures based on the nature of prior work experience in the host or home countries. These findings thus extend the literature on the interplay between social and human capital in entrepreneurship. Personal experience underpins many of the individual influences on internationalisation, yet, despite growing attention to experience in the entrepreneurship literature, few studies open the 'black box' of the logic of experience to understand the reasoning with which it is applied (Jones and Casulli, 2014). As employees of multinational corporations (MNCs), diasporas often encourage their employers to investigate the possibility of investing in the diasporan's country of origin (Kotabe et al., 2013). Our findings in the context of TEs show how prior experience of entering the home country with a former employer, and hence creation of social ties through the former employer, can motivate venture founding in the home country. 
A few limitations of our study open up opportunities for further research. First, we have not explored the role of social ties in the performance of ventures created by TEs. As the success of TEs' ventures depends on maintaining regular contact with their home country (Chung and Tung, 2013), further research may examine if there are any differences in financial performance for each category of TE identified in this paper. As entrepreneurs that receive support from the family are more likely to be successful than those who do not (Bruderl and Preisendörfer, 1998), there is scope to investigate whether TEs that complement family ties with other ties are more successful than others that do not do so. The entrepreneurs' ventures we studied were at an early stage, but further analysis of our cases indicates that although all were on a growth path, they were different in terms of the role of India (market or R\&D centre) in their TNVs, and pace (incremental or rapid) and scope of growth of their TNVs (Table 6). The TEs in Quadrant I were mainly focused on India as a market, and intended to enter emerging or global markets after testing the market in India. The TEs in Quadrant II entered India to sell or locate $\mathrm{R} \& \mathrm{D}$, however, they viewed their market as global, either intending to use, or already having used, their personal connections to penetrate other markets outside of India. Whereas the TEs in Quadrant III had grown very rapidly since inception, with markets (and offices) in UK, US and Asia, besides India, the TEs in Quadrant IV were focused on replicating their experience and expertise in the UK or elsewhere to fill market gaps in India, with no immediate plans for expansion into another market outside of India. The IE literature suggests that entrepreneurs that first enter their home countries to found TNVs are more likely to found ventures that are 'born global' (Oviatt and McDougall, 1994), however, the link between the structure of their social networks and pattern of growth is less understood. Our findings allude to a potential link between TEs' use of networks, and pace and scope of growth; insights that might be worth exploring further in future research.

Second, not all TEs in our sample were born in India. However, all had a link with India. Case $\mathrm{O}$ who was born in Kenya said his grandparents were originally from India, and first migrated to Africa before coming to the UK. Case F said his family originally belonged to Hyderabad (an Indian city), and he was a Bengali (an Indian community) who was born in East Pakistan as his father, an IFS (Indian Foreign Service) officer (and Pakistan and Arab world specialist), was posted there at the time. Case F had strong links with India as he went back to India to study after the family migrated to the UK. The TEs that were born in the UK were second-generation migrants or descendants of Indian-born parents. Our further analysis indicates that these individuals were embedded in India based on strong family connections or frequent travel to India with their respective families since childhood (e.g., Cases B, G, I) and, in some cases (e.g., Case B), even on the basis of time spent studying in India. Prior research on migrant entrepreneurs has looked at migrants that are either first generation, or that are undifferentiated in their embeddedness in the host country. With a small sample it is difficult to draw general insights about the different impact of the heterogeneous background of the entrepreneurs, however we do find that the link with the home country is important even for second-generation migrants. It might be worthwhile for further research, on one hand, to examine whether the home country connection persists or disappears in successive generations and, on the other hand, to explore larger samples that permit a comparison between the different origins of TEs of Indian ethnicity. 
Third, we have not considered whether the TEs returning to India intend to stay there permanently or not. It would be interesting to consider if social ties and hence performance of REs that return home with the intention to live there on a permanent basis are different from those of TEs that maintain regular contact with the home country. Fourth, although our approach is in line with prior work in the area (e.g., Elfring and Hulsink, 2003; Pruthi, 2014), the structure of social networks such as size, strength, diversity or density needs to be considered in future work, insights that may help extend social network theory as applied to entrepreneurship to the case of TEs. Fifth, future work may explore the evolution of TEs' relationships over time (Kreiser et al., 2013). Sixth, as our focus has been on TEs as a subset of migrant entrepreneurs, future research might also explore the effect of different locations of work experience on how other types of migrant entrepreneurs enter markets in their focal country. Seventh, as the role of social capital in venture founding is quite diverse among ethnic communities in developed markets, it may be important to replicate this study to examine TEs of other ethnic origin, as for example those from China in the UK as well as in other developed countries outside of the UK. Finally, all our TEs found TNVs from the position of being based in the host country; it might be interesting to explore if they can also do so from being based in the home country.

\section{Conclusions}

Research on migrant entrepreneurs makes clear distinctions between other types of entrepreneur and TEs that cross host-country borders to commercialise a business idea in their home country. TEs are an important source of innovation that contribute to economic development in both host and home countries, yet, literature on TEs of ethnic origin in developed markets mainly describes the significance of 'transnational communities' for the transfer of knowledge back home. Our findings suggest that TEs exhibit a pattern of substitution or complementarity among personal and industry ties with different actors in venture founding in the host and home countries contingent on whether they have prior experience of:

a entering the home country

b implementing the business opportunity for the TNV in the home country, respectively, with a former employer.

In highlighting the role of social ties with different actors in the host and home countries in the founding of a TNV by TEs, and in identifying the role of prior experience of entering the home country and implementing the business opportunity for the TNV in the home country, respectively, we provide a contingency framework that can form the basis for further empirical work on TEs in India and beyond.

Given the diverse nature of social ties with different actors that TEs use for TNV creation in the home country, our findings imply that policy initiatives to build intermediary networks in the form of market introduction programs or networking organisations to facilitate transnational business cannot be viewed in isolation. They need to be viewed in the context of the nature of prior work experience of these individuals and the business opportunities they wish to pursue in the home country. Therefore, it is important for policy to acknowledge the heterogeneity of TEs and expand the scope of its 
role to matching different types of TEs with different types of social ties they need to cultivate for TNV creation. For TEs considering venture creation in their home country, our findings show that they need to cultivate a range of ties with different actors, be it family or industry. At the same time, however, one size does not fit all in terms of the type of ties they need to develop and utilise. Rather, they need to consider the extent to which they will draw on ties associated with their prior experience of entering the home country with a former employer, and whether they are developing an opportunity that is independent of prior work experience in the home country. It is also evident that different types of ties that TEs develop may either substitute or complement one another based on these dimensions.

\section{Acknowledgements}

This work was supported by the Institute for Small Business and Entrepreneurship (ISBE) - Economic and Social Research Council (ESRC) - Research and Knowledge Exchange (RAKE) Fund [Contract No. RAKE2012-01]. Earlier versions of this paper were presented at the 2015 (Bengaluru, India) and 2016 (New Orleans, USA) annual Academy of International Business (AIB) Meetings. The constructive comments and suggestions of Pavlos Dimitratos, and two anonymous reviewers, are gratefully acknowledged.

\section{References}

Aldrich, H. and Zimmer, C. (1986) 'Entrepreneurship through social networks', in Sexton, D. and x Smilor, D. (Eds.): The Art and Science of Entrepreneurship, Ballinger, Publishing Company, Cambridge, MA.

Anderson, A.R. and Miller, C.J. (2003) 'Class matters: human and social capital in the entrepreneurial process', The Journal of Socio-Economics, Vol. 32, No. 1, pp.17-36.

Arenius, P. and De Clercq, D. (2005) 'A network-based approach on opportunity recognition', Small Business Economics, Vol. 24, No. 3, pp.249-265.

Bagwell, S. (2007) 'Transnational family networks and ethnic minority business development', International Journal of Entrepreneurial Behaviour \& Research, Vol. 14, No. 6, pp.377-394.

Basu, A. (1998) 'An exploration of entrepreneurial activity among Asian small businesses in Britain', Small Business Economics, Vol. 10, pp.313-326.

Bruderl, J. and Preisendörfer, P. (1998) 'Network support and the success of newly founded business', Small Business Economics, Vol. 10, No. 3, pp.213-225.

Buraway, M. (1991) Ethnography Unbound, University of California Press: Berkeley, CA.

Chen, W. and Tan, J. (2009) 'Understanding transnational entrepreneurship through a network lens: theoretical and methodological considerations', Entrepreneurship Theory and Practice, Vol. 33, No. 5, pp.1042-2587.

Chung, H.F.L. and Tung, R. (2013) 'Immigrant social networks and foreign entry: Australia and New Zealand firms in the European Union and Greater China', International Business Review, Vol. 22, No. 1, pp.18-31.

Coviello, N. (2006) 'The network dynamics of international new ventures', Journal of International Business Studies, Vol. 37, No. 5, pp.713-731.

Coviello, N. and Munro, H. (1995) 'Growing the entrepreneurial firm, networking for international market development', European Journal of Marketing, Vol. 29, No. 7, pp.49-61. 
Cucculelli, M. and Morettini, G. (2012) 'Transnational ties in technology-based sectors: the case of Indian software entrepreneurial firms in Italy', International Journal of Entrepreneurship and Small Business, Vol. 17, No. 3, p.319.

Dana, L. and Dana, T. (2005) 'Expanding the scope of methodologies used in entrepreneurship research', International Journal of Entrepreneurship and Small Business, Vol. 2, No. 1, p.79.

Danneels, E. (2002) 'The dynamics of product innovation and firm competences', Strategic Management Journal, Vol. 23, No. 12, pp.1093-1121.

Davidsson, P. and Honig, B. (2003) 'The role of social and human capital among nascent entrepreneurs', Journal of Business Venturing, Vol. 18, No. 3, pp.301-331.

Deakins, D., Ishaq, M., Smallbone, D., Whittam, G. and Wyper, J. (2007) 'Ethnic minority businesses in Scotland and the role of social capital', International Small Business Journal, Vol. 25, No. 3, pp.307-326.

Dhaliwal, S. and Adcroft, A. (2005) 'The sustainability of ethnic minority enterprise: an examination of the asian business sector in the UK', Journal of Asia Entrepreneurship and Sustainability, Vol. 1, No. 2.

Drori, I., Honig, B. and Wright, M. (2009) 'Transnational entrepreneurship: an emergent field of study', Entrepreneurship Theory and Practice, Vol. 33, No.5, pp.1001-1022.

Eisenhardt, K.M. (1989) 'Building theories from case study research', Academy of Management Review, Vol. 14, No. 4, pp.488-511.

Elfring, T. and Hulsink, W. (2003) 'Networks in entrepreneurship: the case of high-technology firms', Small Business Economics, Vol. 21, No. 4, pp.409-422.

Gartner, W., Bird, B. and Starr, J. (1992) 'Acting as if: differentiating entrepreneurial from organizational behavior', Entrepreneurship Theory and Practice, Vol. 16, No. 3, pp.13-21.

Hoskisson, R.E., Eden, L., Lau, C.M. and Wright, M. (2000) 'Strategy in emerging economies', Academy of Management Journal, Vol. 43, No. 3, pp.249-267.

Inkpen, A.C. and Tsang, E.W.K. (2005) 'Social capital, networks, and knowledge transfer'. Academy of Management Review, Vol. 30, No. 1, pp.146-165.

Jack, S. (2005) 'The role, use and activation of strong and weak network ties: a qualitative analysis', Journal of Management Studies, Vol. 42, No. 6, pp.1234-1259.

Janjuha-Jivraj, S. and Woods, A. (2002) 'Successional issues within Asian family firms', International Small Business Journal, Vol. 20, No. 1, pp.77-94.

Johannisson, B., Alexanderson, K.N. and Senneseth, K. (1994) 'Beyond anarchy and organization: entrepreneurs in contextual networks', Entrepreneurship and Regional Development, Vol. 6, No. 4, pp.329-56.

Johanson, J. and Vahlne, J-E. (1990) 'The mechanism of internationalization', International Marketing Review, Vol. 7, No. 4, pp.11-24.

Jones, M. and Casulli, L. (2014) 'International entrepreneurship: exploring the logic and utility of individual experience through comparative reasoning approaches', Entrepreneurship Theory and Practice, Vol. 38, No. 1, pp.45-69.

Kotabe, M., Riddle, L., Sonderegger, P. and Täube, F. (2013) 'Diaspora investment and entrepreneurship: the role of people, their movements, and capital in the international economy', Journal of International Management, Vol. 19, No. 1, pp.3-5.

Kreiser, P.M., Patel, P.C. and Fiet, J.O. (2013) 'The influence of changes in social capital on firmfounding activities', Entrepreneurship Theory and Practice, Vol. 37, No. 3, pp.539-568.

Lewin, A. and Zhong, X. (2013) 'The evolving diaspora of talent: a perspective on trends and implications for sourcing science and engineering work', Journal of International Management, Vol. 19, No. 1, pp.6-13.

Li, Y., Chen, H., Liu, Y. and Peng, M.W. (2014) 'Managerial ties, organizational learning, and opportunity capture: a social capital perspective', Asia Pacific Journal of Management, Vol. 31, No. 1, pp.271-291. 
Light, I., Rezaei, S. and Dana, L. (2013) 'Ethnic minority entrepreneurs in the international carpet trade: an empirical study', International Journal of Entrepreneurship and Small Business, Vol. 18, No. 2, p.125.

Light, I.H. and Gold, S.J. (Eds.) (2000) Ethnic Economies, Emerald Group Publishing Limited, Bingley, UK.

Lorenzen, M. and Mudambi, R. (2013) 'Clusters, connectivity and catch-up: bollywood and bangalore in the global economy', Journal of Economic Geography, Vol. 13, No. 3, pp.501-534.

Maurer, I. and Ebers, M. (2006) 'Dynamics of social capital and their performance implications: lessons from biotechnology start-ups', Administrative Science Quarterly, Vol. 51, No. 2, pp.262-292.

McEwan, C., Pollard, J. and Henry, N. (2005) 'The 'global' in the city economy: multicultural economic development in Birmingham', International Journal of Urban and Regional Research, Vol. 29, No. 4, pp.916-933.

Mosey, S. and Wright, M. (2007) 'From human capital to social capital: a longitudinal study of technology-based academic entrepreneurs', Entrepreneurship Theory and Practice, Vol. 31, No. 6, pp.909-935.

Nahapiet, J. and Ghoshal, S. (1998) 'Social capital, intellectual capital and the organizational advantage', Academy of Management Review, Vol. 23, No. 2, pp.242-266.

O'Donnell, A., Gilmore, A., Cummins, D. and Carson, D. (2001) 'The network construct in entrepreneurship research: a review and critique', Management Decision, Vol. 39, No. 9, pp.749-760.

Onkelinx, J., Manolova, T. and Edelman, L. (2015) 'Human capital and SME internationalization: empirical evidence from Belgium', International Small Business Journal, Vol. 34, No. 6, pp.818-837.

Ostgaard, T. and Birley, S. (1996) 'New venture growth and personal networks', Journal of Business Research, Vol. 36, No. 1, pp.37-50.

Oviatt, B. and McDougall, P. (1994) Journal of International Business Studies, Vol. 25, No. 1, pp.45-64.

Oviatt, B. and McDougall, P. (2005) 'Defining international entrepreneurship and modeling the speed of internationalization', Entrepreneurship Theory and Practice, Vol. 29, No. 5, pp.537-554.

Ozgen, E. and Baron, R.A. (2007) 'Social sources of information in opportunity recognition: effects of mentors, industry networks, and professional forums', Journal of Business Venturing, Vol. 22, No. 2, pp.174-192.

Parthasarathy, B. and Aoyama, Y. (2006) 'From software services to R\&D services: local entrepreneurship in the software industry in Bangalore, India', Environment and Planning, Vol. 38, No. 7, pp.1269-1285.

Patel, P. and Conklin, B. (2010) 'Perceived labor productivity in small firms-the effects of high-performance work systems and group culture through employee retention', Entrepreneurship Theory and Practice, Vol. 36, No. 2, pp.205-235.

Portes, A. and Zhou, M. (1992) 'Gaining the upper hand: economic mobility among immigrant and domestic minorities', Ethnic and Racial Studies, Vol. 15, No. 4, pp.491-522.

Portes, A., Guarnizo, L. and Haller, W. (2002) 'Transnational entrepreneurs: an alternative form of immigrant economic adaptation', American Sociological Review, Vol. 67, No. 2, p.278.

Prashantham, S., Dhanaraj, C. and Kumar, K. (2015) 'Ties that bind: ethnic ties and new venture internationalization', Long Range Planning, Vol. 48, No. 5, pp.317-33.

Pruthi, S. (2014) 'Social ties and venture creation by returnee entrepreneurs', International Business Review, Vol. 23, No. 6, pp.1139-1152.

Ram, M. (1994) 'Unraveling social networks in ethnic minority firms', International Small Business Journal, Vol. 12, No. 3, pp.42-53. 
Ram, M. and Jones, T. (1998) Ethnic Minorities in Business, Small Business Research Trust, Open University Business School, Walton Hall, Milton Keynes MK7 6AA.

Ram, M. and Jones, T. (2008) 'Ethnic minority businesses in the UK: a review of research and policy developments', Environment and Planning C: Government and Policy, Vol. 26, No. 2, pp.352-374.

Ram, M. and Smallbone, D. (2002) 'Ethnic minority business support in the era of the small business service', Environment and Planning C: Government and Policy, Vol. 20, No. 2, pp.235-249.

Sandberg, S. (2014) 'Experiential knowledge antecedents of the SME network configuration in emerging market business networks', International Business Review, Vol. 23, No. 1, pp. $20-29$.

Saxenian, A. (2003) 'Transnational technical communities and regional growth in the periphery', Institutions, Innovation and Growth, Selected Economic Papers.

Saxenian, A. (2005) 'From brain drain to brain circulation: transnational communities and regional upgrading in India and China', Studies in Comparative International Development, Vol. 40, No. 2, pp.35-61.

Saxenian, A. and Hsu, J.Y. (2001) 'The Silicon Valley-Hsinchu connection: technical communities and industrial upgrading', Industrial and Corporate Change, Vol. 10, No. 4, pp.893-920.

Saxenian, A., Motoyama, Y. and Quan, X. (2002) Local and Global Networks of Immigrant Professionals in Silicon Valley, Public Policy Institute of California, No. 58.

Shane, S. (2000) 'Prior knowledge and the discovery of entrepreneurial opportunities', Organization Science, Vol. 11, No. 4, pp.448-469.

Singh, R.P. (2000) Entrepreneurial Opportunity Recognition Through Social Networks, Garland Publishing, Inc., New York \& London.

Steier, L. and Greenwood, R. (2000) 'Entrepreneurship and the evolution of angel financial networks', Organization Studies, Vol. 21, No. 1, pp.163-192.

Suddaby, R. (2010) 'From the editors: what grounded theory is not', Academy of Management Journal, Vol. 49, No. 4, pp.633-642.

Sullivan, D.M. and Ford, C.M. (2013) 'How entrepreneurs use networks to address changing resource requirements during early venture development', Entrepreneurship Theory and Practice, Vol. 38, No. 3, pp.551-574.

Tang, Y.K. (2011) 'The influence of networking on the internationalization of SMES: evidence from internationalized Chinese firms', International Small Business Journal, Vol. 29, No. 4, pp.374-398.

Terjesen, S. and Elam, A. (2009) 'Transnational entrepreneurs' venture internationalization strategies: a practice theory approach', Entrepreneurship Theory and Practice, Vol. 33, No. 5, pp.1093-1120.

Tung, R.L. and Chung, H.F. (2010) 'Diaspora and trade facilitation: the case of ethnic Chinese in Australia', Asia Pacific Journal of Management, Vol. 27, No. 3, pp.371-392.

Uzzi, B. (1997) 'Social structure and competition in inter-firm networks: the paradox of embeddedness', Administrative Science Quarterly, Vol. 42, No. 1, pp.35-67.

Venkataraman, S. (1997) 'The distinctive domain of entrepreneurship research: an editor's perspective', in Katz, J. and Brockhaus, R. (Eds.): Advances in Entrepreneurship, Firm Emergence, and Growth, pp.119-138, JAI Press, Greenwich, CT.

Wadhwa, V.S., Jain, S., Saxenian, A.L., Gerefti, G. and Wang, H. (2011) 'The grass is indeed greener in India and China for returnee entrepreneurs: America's new immigrant entrepreneurs', Part VI', Kauffman: The Foundation for Entrepreneurship, April 2011.

Wagner, D., Head, K. and Ries, J. (2002) 'Immigration and the trade of provinces', Scottish Journal of Political Economy, Vol. 49, No. 5, pp.507-525.

Waldinger, R. and Fitzgerald, D. (2004) 'Transnationalism in question', American Journal of Sociology, Vol. 109, No. 5, pp.1177-1195. 
Wright, M., Hmieleski, K., Siegel, D. and Ensley, M. (2007) 'The role of human capital in technological entrepreneurship', Entrepreneurship Theory and Practice, Vol. 31, No. 6, pp.791-806.

Yang, X., Ho, E. and Chang, A. (2012) 'Integrating the resource-based view and transaction cost economics in immigrant business performance', Asia Pacific Journal of Management, Vol. 29, No. 3, pp.753-772.

Yeung, H. (2009) 'Transnationalizing entrepreneurship: a critical agenda for economic Geography', Progress in Human Geography, Vol. 33, No. 2, pp.210-235.

Yin, R.K. (1994) Case Study Research: Design and Methods, 2nd ed., Sage, London. 